\title{
Editorial Foreword 73.3 (August 2014)
}

\section{Our Cover}

This month's cover has ties to the two essays that open the current issue, which deal, in very different ways, with the writings and career of Lu Xun (1881-1936), who is often called China's most influential twentieth-century literary figure. It shows one of the many political posters from China's Mao era (1949-76) that turned the famously iconoclastic writer into a simplistic propaganda symbol. The image comes to us courtesy of Stefan R. Landsberger, Associate Professor of Contemporary Chinese History at the University of Leiden and Professor of Contemporary Chinese Culture at the University of Amsterdam. It is part of the International Institute of Social History/Stefan R. Landsberger collection at the Landsberger Sinological Institute housed in Leiden University, call number: BG E13/595, found at http://chineseposters.net/posters/e13-595.php. The $77 \times 105.5$ centimeter poster was designed by Chen Yaoyi (陈尧伊) in March 1973 and published by Renmin meishu chubanshe (人民美术出版社). The caption on the poster says “Study Lu Xun's revolutionary spirit to become a pathbreaker in criticizing Lin Biao and Confucius" (Xuexi Lu Xunde geming jingshen zuo pi Lin pi Kongde chuangjiang 学习鲁迅的革命精神做批林批孔的闯将).

\section{ReseArch Articles}

This issue is a wonderfully varied one in terms of the topics, texts, and times that contributors address as well as the places and problems that interest them. The authors represented in the pages of the articles section that opens this volume, moreover-as well as, of course, in the Book Reviews section that closes it - are located in disparate parts of world (contributors of articles in this issue are currently working in India, France, Germany, Australia, the United Kingdom, and the United States) and based in many different departments (Chinese, Anthropology, History, Economic History, etc.) in varied types of institutions (from research universities to liberal arts colleges to a social science academy). They bring an array of theoretical approaches and methodologies to bear in essays that explore and make use of texts ranging from an ancient Chinese classic (the Yijing or Book of Changes) to the Qur'an, from essays by Lu Xun and writings by Gandhi, to comics and police files.

This diverse issue begins with "Lu Xun on Our Minds: The Post-Socialist Reappraisal," a Trends essay by Chinese literature specialist Jon Eugene von KowaLLis of the University of New South Wales. His focus is on three recent scholarly studies of this author, who is widely considered twentieth-century China's most influential literary figure. As befits contributions to the Trends genre, he uses this trio of books as a 
vantage point from which to comment on broad developments in a significant scholarly field_and "Lu Xun Studies" certainly qualifies as that, given how much attention the author has received, not only in Sinophone and Anglophone academic circles, but from specialists in literature and cultural history working in other languages as well. Kowallis charts a shift from Cold War era Western approaches to the author, in which $\mathrm{Lu}$ Xun's sympathies with the Communist Party late in life loom large, to new approaches, which he terms "post-socialist" due to their being less tightly focused on political allegiances and alignments. Kowallis ends by musing on whether a transnational turn in work on Lu Xun may come next.

This opening essay sets the stage very nicely for the issue's first standard research article, which is a work on Lu Xun by Eileen J. Cheng of Pomona College, who happens to be among the authors whose books Kowallis discusses. It seems, in fact, as though her essay, “In Search of New Voices from Alien Lands': Lu Xun, Cultural Exchange, and the Myth of Sino-Japanese Friendship," could have been written to take up the challenge to globalize studies of the author laid down in the final paragraphs of his piece. For as the title of her contribution suggests, Cheng is concerned in part with Lu Xun's transnational activities, as a translator of international literature and as someone intrigued by not just literary flows but also personal ties that crossed borders. This is a happy convergence rather than the result of a plan, however, as the Trends piece by Kowallis began as a review essay commissioned by Book Review Editors Yili $\mathrm{Wu}$ and Christian de Pee, and only later was found to consider broad enough issues to be best placed within the articles section of the issue, while the Cheng essay was a noncommissioned one, submitted through the regular channels.

In another unplanned convergence, this issue contains two other articles dealing with the flow of texts across borders. These come immediately after Cheng's article-their placement there was intentional, an effort to make the most of accidental synergy. The first of the two, by Hans Martin Krämer of the University of Heidelberg, is “Pan-Asianism's Religious Undercurrents: The Reception of Islam and Translation of the Qur'ān in Twentieth-Century Japan." It draws attention to the "religious dimension" of Japanese pan-Asianism, which has often been "overlooked" in discussion of the topic, according to the author.

The article that comes after that, by Gregory N. Evon of Australia National University, is "Tobacco, God, and Books: The Perils of Barbarism in Eighteenth-Century Korea." It also deals with religious texts, but from a very different vantage point than that taken by Krämer. It explores a Korean "literary inquisition" aimed at defending orthodoxy, which took place at roughly the same time that better-known official attacks on allegedly dangerous works were underway in both China and Japan. It was triggered partly by worries in Korea about Catholic and other heterodox beliefs flowing into the country from the neighboring lands of the Qing Empire.

These opening essays are followed by two studies of South Asian history. The first of these, by Charu Gupta of the University of Delhi, is titled "Intimate Desires: Dalit Women and Religious Conversions in Colonial India." Breaking with the tendency by scholars to focus on the appeal that Islam and Christianity had for Dalit men, it explores various aspects of the "interrelationship between caste and gender" by making use of an eclectic source base, comprised of everything from works of "vernacular missionary 
literature" to the "writings of Hindu publicists and caste ideologues," and from cartoons to police reports.

Following this grassroots look at the experiences of ordinary people comes a revisionist study of the most famous figure in modern Indian history: Gandhi. Written by MARIA Misra, a scholar at Keble College, Oxford, and titled "Sergeant Major Gandhi: Indian Nationalism and Nonviolent 'Martiality," it argues that works stressing the eponymous leader's "importance as a global theorist of principled nonviolence" has obscured the importance of "martial attitudes" as well as pacific practices in his calls for his compatriots to work to end colonial rule. The author argues that, conventional wisdom notwithstanding, Gandhi's "thinking on the issue of violence" needs to be seen as "complex and sometimes contradictory" and that a full assessment of his philosophy needs to come to terms with his advocacy of what is best termed "nonviolent 'martiality' rather than nonviolence per se."

The issue's next article, Katherine A. Bowie's "Of Buddhism and Militarism in Northern Thailand: Solving the Puzzle of the Saint Khruubaa Srivichai," also deals, as its title suggests, with the ways that pacifist ideas and martial visions can become entwined. The University of Wisconsin-Madison anthropologist argues that to make sense of the figure whose life and reputations concern her-a Buddhist monk who lived from 1878 to 1938 and is now "revered as a saint in northern Thailand today," even though while alive he was "detained under temple arrest on multiple occasions"-we need to pay close attention to "changing policies regarding military conscription" in the past. We also need to realize that, while there are certainly important pacifist strains within Buddhism, there can be serious limitations, when dealing with history as well as contemporary events, with the notion that has taken hold in the "Western imaginary" that the religion's name and the word "nonviolence" are "almost synonymous."

Closing the issue's articles section are two essays that take us from South and Southeast Asia to China and then to Japan. The first of these, Stéphanie Homola’s "The Fortunes of a Scholar: When the Yijing Challenged Modern Astronomy," looks at a fascinating and long-lived figure, Liu Zhihua, who was born in China in 1899 and died there in 1992, but spent an important part of his life in France, earning a doctorate in astronomy from the Sorbonne in 1940. Homola, an anthropologist based at the École des Hautes Études en Sciences Sociales in Paris, uses the ups and downs of Liu's career, as well as his efforts to show that an ancient Chinese text could complement modern scientific investigations, to shed light on a wide range of issues, including the "the role of analogy in cultural assimilation" and the unsettling effects that the introduction of "modern Western categories of science, religion, and superstition" could have in China in the early 1900s.

The final article, LSE economic historian JAnEt HunTER's “'Extreme Confusion and Disorder?? The Japanese Economy in the Great Kantō Earthquake of 1923," provides a close look at how Japan, a country whose responses to 2011's catastrophic events have received considerable attention in recent issues of this journal, reacted to an important twentieth-century disaster. She is intrigued by the fact that 1923's earthquake had only a "limited impact" on Japan's "economic trajectory," despite intense contemporary anxiety that the country's markets and productivity would be derailed by it. This phenomenon "can tell us a great deal," Hunter claims, about what makes responses to disaster 
more and less effective, "not just in Japan, but more broadly," providing we look closely at how exactly quickly "reestablishing market stability" following the catastrophe was possible in this case.

\section{Forthcoming Articles in JAS 73.4 (November 2014)}

\section{Asia Beyond the Headlines}

Reading National Restoration and Regional Reemergence in Myanmar's Southeast Asian Games of 2013

Simon Creak

Presidential Address

Asian Studies across Academies

ThongChai Winichakul

\section{Reflections}

Chinese Xenology and the Opium War: Personal Reflections on Sinocentrism Dilip K. BASU

Citizen Ai: Warrior, Jester, and Middleman

William A. Callahan

Citizen Intellectuals in Historical Perspective: Reflections on Callahan’s "Citizen Ai" Timothy Cheek

\section{JAS at AAS Roundtable}

Placing Asia in the Anthropocene: Histories, Vulnerabilities, Responses

MARK J. HudSON

Crossing the Bridge between Specialized Knowledge and Breadth of Vision Regarding Climate Change and Asia

ISABEL HiLTON

Climate Change: What's Asian Studies Got to Do with It?

Kavita Philip

$(\text { Asian Studies + Anthropocene })^{4}$

Johan Elverskog

Literature, Asia, and the Anthropocene: Possibilities for Asian Studies and the Environmental Humanities

Karen L. Thornber 
Wither Southeast Asia in the Anthropocene?

Gene Ammarell

Research Articles

Picturing Gentlemen: Japanese Portrait Photography in Colonial Taiwan Joseph R. AlLen

Music for Inner Domains: Sinhala Song and the Arya and Hela Schools of Cultural Nationalism in Colonial Sri Lanka

Garrett Matthew Field

Religious Resurgence, Authoritarianism, and "Ritual Governance": Baci Rituals, Village Meetings, and the Developmental State in Rural Laos

SARINDA SINGH 